\title{
Precise aerial fertiliser application on hill country
}

\author{
A.G. GILLINGHAM ${ }^{1}$, J. MABER ${ }^{2}$, J. MORTON $^{3}$ and M. TUOHY \\ ${ }^{1}$ AgResearch Grasslands, Palmerston North \\ ${ }^{2}$ Lincoln Ventures, Hamilton \\ ${ }^{3}$ AgResearch, Invermay, Dunedin \\ ${ }^{4}$ Institute of Natural Resources, Massey University, Palmerston North
}

\section{Abstract}

The fertiliser requirements of hill country vary with soil type, slope and aspect-related factors which govern pasture production potential and species composition. In most situations, the topographic complexity is such that only very broad differentiation in land units can be made when aerially applying fertiliser. The traditional method of aerial topdressing is for superphosphate to be flown on at a common rate over large blocks of complex topography by fixed-wing aircraft. Advances in geographical positioning system (GPS) and aircraft technology now allow aircraft to fly accurately defined track spacing and so achieve optimum uniformity of fertiliser spread. The same technology could be used to vary fertiliser application rate along a flight path according to predetermined recommendations and through links to a farm geographic information system (GIS) map. This approach could also be used to apply different fertiliser types. In a desktop study the effects of differential, compared with uniform, fertiliser application policies, on animal productivity and economic returns were examined for three contrasting hill farm situations using a combination of trial results and the AgResearch PKS Lime Programme. Results showed that for a farm with a low soil $\mathrm{P}$ status (Olsen $\mathrm{P}=9$ ), that stocking rate could be increased by $0.5 \mathrm{su} / \mathrm{ha}$, and the economic return by $7.5 \%$, by differential, rather than uniform fertiliser application. In a similar but higher soil $\mathrm{P}$ status farm (Olsen $\mathrm{P}=15)$, the increase was $0.9 \mathrm{su} /$ ha and $10.1 \%$ respectively. In a summer-dry situation where nitrogen fertiliser could be substituted for some P fertiliser, a differential policy designed to optimise production gave a $2.1 \mathrm{su} / \mathrm{ha}$ and $43 \%$ net margin increase, compared with the uniform application of a typical rate of maintenance $P$ fertiliser only. The results from the desktop study are discussed in relation to the practical aspects of developing differential fertiliser application methods. This will relate to extra fertiliser application cost, and the definition of practical sized land units and fertiliser forms, which will all have some effect on the net economics of a differential application policy. Despite these unknowns, the technology would appear to offer real gains to the hill country farmer.

Keywords: economic return, fertiliser application, GIS, GPS, hill country, phosphate

\section{Introduction}

The fertiliser requirements of hill country pastures vary with soil type, slope and aspect-related factors which govern production potential and species composition (Gillingham 1973; Lambert et al. 1983a, 1983b). In most situations the complexity of slopes and aspects is such that only very broad differentiations between soil types or topography are made in fertiliser recommendations for farmers. For most hill farms the benefits of fertiliser are well understood and the traditional approach is for predominantly superphosphate to be flown on at a uniform rate over large blocks of hill country by fixed-wing aircraft. Refinements in aircraft technology have kept the application costs of such fertiliser relatively stable for many years. At the same time there has been considerable attention given to minimising the variability of fertiliser application.

Despite these advances the general requirement of farmers is to have fertiliser applied at the lowest cost. This is because significant advantages of improved uniformity of spread have not been demonstrated. For regularly fertilised pasture, the benefits of reducing the variability of phosphate fertiliser application are estimated to be about only $\$ 0.50$ /ha (Chaio \& Gillingham 1989), because of the high residual value of phosphate fertiliser (Scobie \& St-Pierre 1987). The benefits of uniform fertiliser application are greater where capital applications of $\mathrm{P}$ fertiliser are applied to low fertility soils, or where nitrogen $(\mathrm{N})$ or sulphur (S) fertilisers with lower residual effects, are applied (Chaio \& Gillingham 1989).

GPS and GIS technology and the relevance to differential aerial fertiliser application

The Global Positioning System (GPS) is based on a constellation of over 20 satellites orbiting the earth. GPS satellites transmit timing reference signals which the receivers in aircraft use to determine their distance 
from each satellite. Using simultaneous distances from a minimum of three satellites, a precise three-dimensional position of the aircraft can be calculated. The most common use of the equipment is to allow a pilot to fly uniformly spaced flight paths using a visual reference, such as a panel of lights in the cockpit which indicate any variation from the designated route. In addition to giving a precise location, the GPS system also provides information on the ground speed of the aircraft (but not the airspeed).

Geographic Information Systems (GIS) are computer databases used to input, store, manipulate, analyse and output geographically referenced information. For example, a DEM (digital elevation model) can be analysed to produce both slope and aspect maps. These in turn may be interpreted to provide information on the spatial distribution of land units that have different nutrient requirements. Digitised GIS farm maps can now be prepared which will specify separate topographic units, and or, soil types, as well as waterways, tracks and other non-productive areas.

The actual fertiliser application rate from an aircraft is a function of ground speed, flow rate of fertiliser from the hopper (a function of hopper outlet) and flight path spacing (Gillingham et al. 1985). The ground speed signal from the GPS system offers the possibility to automatically adjust the hopper outlet according to the actual ground speed. The ability to identify precisely where the aircraft is located over an area means that a required application rate at that point could be achieved if the aircraft ground speed and the track spacing are known.

The combination of GPS and GIS systems provides the ability to make the aircraft a more versatile and accurate application device without compromising the safety of the pilot by diverting attention away from flying the aircraft. These advances in GIS and GPS technology may have a potential role in enabling aircraft to deliberately vary, or cease, fertiliser application rate along a flight path in order to meet differences in optimum fertiliser requirements of contrasting hill land zones. The same flight path can subsequently be used to strategically apply a different fertiliser type.
This paper presents results from a desktop study which examines the results from differential aerial application of fertiliser to three hill country situations and compares the economics with the current, uniform application approach, in order to evaluate if there are real benefits to be obtained by the hill farmer from such technology.

\section{Methods}

Digitised maps were prepared from topographic details of typical, actual hill farm blocks in contrasting climatic regions. Two farms were in a moist Manawatu climate, where pasture clover content was moderate. Variation in the initial Olsen soil P level and associated fertiliser $\mathrm{P}$ application rates only were specified. The third farm was in the summer dry North Island East Coast, where clover was largely absent from steep slopes and where $\mathrm{P}$ and/or $\mathrm{N}$ fertiliser types were specified for differing land units.

For each farm, individual land management units were identified with details of slope, defined from 5 or $20 \mathrm{~m}$ contour interval digital terrain maps and separated into flat ( $0-12$ degrees), easy (13-25 degrees), and steep (26+ degrees) land zones, and aspects, soil type, grazing animal type and stocking rate, soil Olsen P test, and soil $\mathrm{S}$ status.

For each land management unit a $\mathrm{P}$ fertiliser recommendation was derived, using the AgResearch PKS Lime model, which would maintain production at the current level. The model also calculated the associated stocking rates and economic net margin. Net margin ( $\$ /$ ha) was derived as the gross margin less stock and total fertiliser costs $(\$ / \mathrm{ha})$.

\section{Manawatu moist hill country}

\section{Farm 1: Low fertility (Table 1)}

A farm with an assessed 46:48:6\% mix of flat, easy and steep slopes, and with an Olsen soil P test of 9 on all sites was mapped. Long-term trial results show that the soil $\mathrm{P}$ test on easy and steep slopes is similar from application of a similar fertiliser rate (Whatawhata rates of $\mathrm{P}$ trial results, unpublished). Production was compared

Table 1 Predicted effects of differential compared with uniform $P$ fertiliser application to low fertility, moist hill country (Farm 1).

\begin{tabular}{|c|c|c|c|c|c|c|c|c|c|}
\hline & \multicolumn{4}{|c|}{--------------- Uniform Application --------------- } & \multicolumn{4}{|c|}{----------- Differential Application -------------- } & \multirow[b]{2}{*}{$\begin{array}{c}\text { Net } \\
\text { margin } \\
\text { difference (\%) }\end{array}$} \\
\hline & $\begin{array}{c}\text { Olsen } \\
\text { P }\end{array}$ & $\begin{array}{l}\text { Stocking } \\
\text { rate } \\
\text { (su/ha) }\end{array}$ & $\begin{array}{c}\text { Maintenance } \\
\text { P rate } \\
\text { (kg/ha) }\end{array}$ & $\begin{array}{l}\text { Net } \\
\text { margin } \\
(\$ / \text { ha })\end{array}$ & $\begin{array}{c}\text { Olsen } \\
\mathrm{P}\end{array}$ & $\begin{array}{l}\text { Stocking } \\
\text { rate } \\
(\mathrm{su} / \mathrm{ha})\end{array}$ & $\begin{array}{c}\text { Maintenance } \\
\text { P rate } \\
\text { (kg/ha) }\end{array}$ & $\begin{array}{c}\text { Net } \\
\text { margin } \\
(\$ / \text { ha })\end{array}$ & \\
\hline Flat & 9 & 11 & 9 & 234 & 11 & 13 & 11 & 280 & \\
\hline Easy & 9 & 6 & 9 & 107 & 8 & 5 & 8 & 86 & \\
\hline Steep & 9 & 3 & 9 & 41 & 5 & 3 & 6 & 49 & \\
\hline \multicolumn{10}{|l|}{ Weighted } \\
\hline average & 9 & 8 & 9 & 161 & 9.2 & 8.5 & 9.2 & 173 & 7.5 \\
\hline
\end{tabular}


for uniform and differential fertiliser application strategies which maintained about the same overall farm soil $\mathrm{P}$ status and which used the same amount of $\mathrm{P}$ fertiliser. Sheep and beef stocking rates (su/ha) were derived from the AgResearch PKS Lime model for each situation.

Uniform fertiliser policy: The maintenance $\mathrm{P}$ requirement was $9 \mathrm{~kg} \mathrm{P} /$ ha overall for an average stocking rate of $8 \mathrm{su} / \mathrm{ha}$. This rate was calculated as the mean for Flat, Easy and Steep slopes.

Differential fertiliser policy: Under a differential fertiliser policy the farm also had an overall mean soil $P$ level of near 9 (9.2) and used about the same average maintenance P fertiliser rate of about $9(9.2) \mathrm{kg} / \mathrm{ha}$, but this was generated by increasing fertiliser application to flat areas, which had an Olsen P level of 11, and by reducing $P$ fertiliser application to steep areas in particular where the Olsen $P$ level was allowed to drop to 5. Differential maintenance $P$ rates for an average soil Olsen P level of 9.2 were 11, 8 and $6 \mathrm{~kg} / \mathrm{ha}$ for Flat, Easy and Steep strata respectively.

\section{Farm 2: Medium fertility (Table 2)}

A farm with an assessed 46:48:6\% mix of flat, easy and steep slopes, and with an overall Olsen soil P test of 15 was mapped. Production was compared for uniform and differential fertiliser application strategies as for Farm 1.

Uniform fertiliser policy: The uniform maintenance $\mathrm{P}$ requirement was $14 \mathrm{~kg} \mathrm{P} / \mathrm{ha}$ overall for an average stocking rate of $11.2 \mathrm{su} / \mathrm{ha}$. This requirement was calculated as the mean for Flat, Easy and Steep slopes.

Differential fertiliser policy: Under a differential fertiliser policy the farm also had a mean soil P level of near 15 (15.8) and used about the same average maintenance P fertiliser rate of about 14 (14.4) kg/ha but this was generated by increasing fertiliser application to flat areas, which had an Olsen P level of 18, and by reducing $\mathrm{P}$ fertiliser application to steep areas in particular, which had an Olsen $P$ level of 5. The differential fertiliser $P$ rates required in order to maintain an average Olsen P level of 15.8, were 16, 14 and $6 \mathrm{~kg}$ $\mathrm{P} /$ ha for Flat, Easy and Steep strata respectively.

\section{East Coast summer dry hill country}

Farm 3: Low fertility, dry hill country (Table 3)

A farm block with predominantly north and south facing easy and steep slopes (with $84 \%$ in easy slopes and $16 \%$ in steep slopes) was mapped.

Uniform fertiliser policy: The soil Olsen $\mathrm{P}$ test average was 8 and increased overall to 12 by application of $20 \mathrm{~kg} \mathrm{P} / \mathrm{ha}$. An overall maintenance fertiliser P application rate of $14 \mathrm{~kg} / \mathrm{ha}$ was subsequently applied.

Differential fertiliser policy: The differential fertiliser strategy was based on results from the Waipawa fertiliser trial (Gillingham et al. 1998) which showed that land areas with little clover in the pasture should receive only low rates of $\mathrm{P}$ and $\mathrm{S}$ fertiliser plus $\mathrm{N}$ fertiliser to overcome the basic $\mathrm{N}$ deficiency. The differential policy applied $\mathrm{P}$ fertiliser selectively at 40

Table 2 Predicted effects of differential compared with uniform P fertiliser application to moderate fertility, moist hill country (Farm 2).

\begin{tabular}{|c|c|c|c|c|c|c|c|c|c|}
\hline & \multicolumn{4}{|c|}{-------------- Uniform Application --------------- } & \multicolumn{4}{|c|}{ 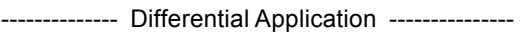 } & \multirow[b]{2}{*}{$\begin{array}{c}\text { Net } \\
\text { margin } \\
\text { difference }(\%)\end{array}$} \\
\hline & $\begin{array}{c}\text { Olsen } \\
\text { P }\end{array}$ & $\begin{array}{l}\text { Stocking } \\
\text { rate } \\
\text { (su/ha) }\end{array}$ & $\begin{array}{c}\text { Maintenance } \\
\text { P rate } \\
\text { (kg/ha) }\end{array}$ & $\begin{array}{c}\text { Net } \\
\text { margin } \\
(\$ / \text { ha })\end{array}$ & $\begin{array}{c}\text { Olsen } \\
\text { P }\end{array}$ & $\begin{array}{c}\text { Stocking } \\
\text { rate } \\
\text { (su/ha) }\end{array}$ & $\begin{array}{c}\text { Maintenance } \\
\mathrm{P} \text { rate } \\
(\mathrm{kg} / \mathrm{ha})\end{array}$ & $\begin{array}{c}\text { Net } \\
\text { margin } \\
(\$ / \text { ha })\end{array}$ & \\
\hline Flat & 15 & 15.8 & 14 & 343 & 18 & 18 & 16 & 393 & \\
\hline Easy & 15 & 7.7 & 14 & 138 & 15 & 7.7 & 14 & 138 & \\
\hline Steep & 15 & 4.7 & 14 & 62 & 5 & 3 & 6 & 65 & \\
\hline $\begin{array}{l}\text { Weighted } \\
\text { average }\end{array}$ & 15 & 11.2 & 14 & 228 & 15.8 & 12.1 & 14.4 & 251 & 10.1 \\
\hline
\end{tabular}

Table 3 Predicted effects of differential compared with uniform P fertiliser application to low fertility, summer dry hill country, combined with some substitution of $\mathrm{N}$ for $\mathrm{P}$ fertiliser (Farm 3).

\begin{tabular}{|c|c|c|c|c|c|c|c|c|c|c|}
\hline \multirow[t]{2}{*}{ Aspect } & \multirow[t]{2}{*}{ Slope } & \multicolumn{4}{|c|}{--------- Uniform Fertiliser Application --------- } & \multicolumn{5}{|c|}{------- Differential Fertiliser Application } \\
\hline & & $\begin{array}{c}\text { Capital } \\
\text { P } \\
\text { (kg/ha) }\end{array}$ & $\begin{array}{c}\text { Maintenance } \\
\mathrm{P} \\
(\mathrm{kg} / \mathrm{ha})\end{array}$ & $\begin{array}{l}\text { Stocking } \\
\text { rate } \\
\text { (su/ha) }\end{array}$ & $\begin{array}{l}\text { Net } \\
\text { Margin } \\
(\$ / \text { ha })\end{array}$ & $\begin{array}{c}\text { Capital } \\
\text { P } \\
\text { (kg/ha) }\end{array}$ & $\begin{array}{c}\text { Mainte } \\
\mathrm{P} \\
(\mathrm{kg} /\end{array}$ & $\begin{array}{l}\mathrm{N} \\
\text { ha) }\end{array}$ & $\begin{array}{c}\text { Stocking } \\
\text { rate } \\
\text { (su/ha) }\end{array}$ & $\begin{array}{c}\text { Net } \\
\text { margin } \\
(\$ / \text { ha })\end{array}$ \\
\hline \multirow[t]{2}{*}{ North } & Easy & 20 & 14 & 10.6 & & 40 & 21 & & 13.1 & \\
\hline & Steep & 20 & 14 & 5.9 & & & 14 & 30 & 9.2 & \\
\hline South & Easy & 20 & 14 & 9.3 & & 40 & 19 & & 10.1 & \\
\hline \multicolumn{11}{|l|}{ Weighted } \\
\hline Average & & 20 & 14 & 8.9 & 185 & 33 & 19 & 5 & 11 & 266 \\
\hline
\end{tabular}


$\mathrm{kg}$ P/ha to raise the Olsen soil P level to 16 on easy slopes only. The resulting maintenance fertiliser $\mathrm{P}$ application rate was about $20 \mathrm{~kg} / \mathrm{ha}$ on these areas. The steep slopes remained at an Olsen soil P test of 8 and received maintenance $\mathrm{P}$ fertiliser according to stocking rate requirements. Thirty $\mathrm{kg} \mathrm{N} / \mathrm{ha}$ was applied to steep slopes only in early winter. Stocking rates were derived from trial results. Net margin was calculated from an Agriculture New Zealand spreadsheet (R.Fraser pers. comm.) as gross margin less maintenance fertiliser costs, less interest on any capital fertiliser and on any increase in stock numbers as a result of the differential policy.

\section{Results}

\section{Manawatu moist hill country}

At the low P fertility level (Table 1), the differential fertiliser policy resulted in an increase in stocking rate of $0.5 \mathrm{su} / \mathrm{ha}$ and an increase in net margin of $\$ 12 / \mathrm{ha}$, i.e., about a $7.5 \%$ increase at the same average soil $\mathrm{P}$ level (i.e., Olsen $P=9.2$ compared with 9 ) and average $\mathrm{P}$ application rate (i.e., 9.2 c.f. $9 \mathrm{~kg} / \mathrm{ha}$ ).

At the medium $\mathrm{P}$ fertility level (Table 2), the Differential fertiliser policy resulted in an increase in stocking rate of $0.9 \mathrm{su} / \mathrm{ha}$ and an increase in net margin of $\$ 23 /$ ha, i.e., about a $10.1 \%$ increase at the same average soil $\mathrm{P}$ level (i.e., Olsen $\mathrm{P}=15.8$ compared with 15 ) and average $\mathrm{P}$ application rate (i.e., $14.4 \mathrm{cf} .14 \mathrm{~kg} / \mathrm{ha}$ ).

\section{East Coast summer dry hill country}

The differential fertiliser policy was designed to maximise production on easy slopes, and incorporated the additional strategic use of $\mathrm{N}$ fertiliser to steep slopes (Table 3). This increased stocking rate from 8.9 to $11 \mathrm{su} /$ ha and increased the economic net margin from $\$ 185 /$ ha to $\$ 266 /$ ha or by $43 \%$. This was accomplished by both increasing productivity on easy slopes with $\mathrm{P}$ fertiliser, and on steep slopes with $\mathrm{N}$ fertiliser.

\section{Discussion}

The adoption of a differential fertiliser application policy on a hill country farm requires more detailed information on pasture productivity from contrasting topographic land units, and the associated responsiveness to $\mathrm{P}$ and $\mathrm{N}$ fertilisers, than is needed to provide a general, uniform recommendation for the same property. A uniform recommendation is usually based on the average stocking rate and the predominant topographic class of the farm, i.e., flat, easy or steep slopes. With a differential fertiliser policy, the differing efficiencies of production or responsiveness to fertiliser on contrasting landforms must be incorporated into the recommendation. For example the AgResearch PKS Lime Programme calculates that the production of a stock unit from steep slopes will take $1.1 \mathrm{~kg} \mathrm{P}$, whereas on flat land the same stock unit requires only $0.3 \mathrm{~kg} \mathrm{P}$, and $0.7 \mathrm{~kg} P$ on easy slopes to replace animal related losses of $\mathrm{P}$ (soil related factors will require about another $0.6 \mathrm{~kg} \mathrm{P} / \mathrm{Olsen} \mathrm{P}$ unit over the soil test range of 15-25). The slope related differences in animal losses of $\mathrm{P}$ are due to the greater transfer of $\mathrm{P}$ from sloping land by grazing stock. So it is generally more efficient to maximise production on flat land areas before increasing pasture growth on slopes, and on steep slopes in particular. The differential fertiliser policy therefore gives preference in use of limited fertiliser to flat and easy sloping sites.

\section{Manawatu moist hill country}

For the Low P fertility property (Farm 1), the uniform application of $9 \mathrm{~kg} \mathrm{P} /$ ha supported an average of $8 \mathrm{su} /$ ha. However in reality this is made up from $46 \%$ of the area as flat land supporting $11 \mathrm{su} / \mathrm{ha}, 48 \%$ of the farm as easy land carrying $6 \mathrm{su} / \mathrm{ha}$, and $6 \%$ of the farm as steep land carrying $3 \mathrm{su} / \mathrm{ha}$. The aim of differential topdressing was to use the same amount of fertiliser as recommended for a uniform application, but to give preference to the flat sites and reduce fertiliser application to steep areas. Productivity on the flat areas was increased to $13 \mathrm{su} / \mathrm{ha}$ and the stocking rate on the easy land was reduced to 8 $\mathrm{su} / \mathrm{ha}$.. The stocking rate on the steep land was able to be maintained at $3 \mathrm{su} / \mathrm{ha}$ by the reduced fertiliser application of $6 \mathrm{~kg} \mathrm{P} / \mathrm{ha}$ indicating that the higher rate applied under the uniform regime $(9 \mathrm{~kg} \mathrm{P} / \mathrm{ha})$ was not needed to support this low stocking rate. As a result the economic net margin increased by $7.5 \%$ with no change in fertiliser costs. An alternative approach would have been to completely eliminate fertiliser from the steep land and apply it preferentially to the flat areas. This would have increased stocking rate on those areas even more, but may have resulted in reversion of pasture on the steep land. The preferred approach would be to increase fertiliser application to the flat sites and to maintain soil P levels on the steep sites i.e., increase the total fertiliser used. This is also likely to further increase the economic net margin.

On the moderate fertility, moist, hill country farm (Farm 2), the same rationale was applied with even more emphasis on preferentially fertilising the flat and easy land areas but maintaining the steep land at only a low soil P level (i.e., Olsen $\mathrm{P}=5$ ). The effect was to increase overall stocking rate by $0.9 \mathrm{su} / \mathrm{ha}$ and the economic net margin by $10.1 \%$ with about the same total fertiliser use.

\section{East Coast summer dry hill country}

In this example the differential policy incorporated results from the Waipawa fertiliser trial (Gillingham et al. 1998) 
which show that partial substitution of $\mathrm{N}$ for $\mathrm{P}$ fertiliser on steep areas is the most effective means of increasing pasture production. Under the uniform application method, $20 \mathrm{~kg} / \mathrm{ha}$ of capital $\mathrm{P}$ is applied overall, together with an annual maintenance dressing of $14 \mathrm{~kg} \mathrm{P} / \mathrm{ha}$. This supports $10.6 \mathrm{su} / \mathrm{ha}$ on the easy, north slopes, 5.9 $\mathrm{su} / \mathrm{ha}$ on the steep, north slopes, $9.3 \mathrm{su} / \mathrm{ha}$ on easy, south facing slopes and $4.6 \mathrm{su} / \mathrm{ha}$ on steep, south slopes to give an average stocking rate of $8.9 \mathrm{su} / \mathrm{ha}$ and an economic net margin of $\$ 185 /$ ha. This compares to the MAF Farm Monitoring Report for the North Central region (July 1998) which has a model Hawke's BayWairarapa summer dry hill country farm with an average stocking rate over the last 4 years of $8.5 \mathrm{su} / \mathrm{ha}$ and an average cash farm surplus (gross farm revenue less gross cash expenditure) of $\$ 134 /$ ha over the same period.

Under the differential fertiliser application policy enough capital fertiliser $\mathrm{P}$ is applied to the easy slopes alone to raise the soil $\mathrm{P}$ level on these areas to 16 , and the steep slopes are maintained at an Olsen P level of 8 . The use of $\mathrm{N}$ fertiliser on steep slopes increases pasture production and associated stocking rate. Consequently maintenance $P$ fertiliser is also increased on these areas to support the higher stocking rate. The combined effect of this policy is to increase stocking rate on all strata and over the whole farm by $2.1 \mathrm{su} / \mathrm{ha}$ to $11 \mathrm{su} / \mathrm{ha}$. The net margin increases by about $43 \%$ from $\$ 185 /$ ha to \$266/ha.

The benefits from the differential fertiliser application policy were greater where there was some substitution of $\mathrm{N}$ for $\mathrm{P}$ fertiliser on steep slopes, which resulted in a significant increase in pasture production. However a major part of the production increase is also attributable to the differential application of the capital $P$ fertiliser and the greater continuing benefit of this on easy slopes only. Under a conventional, uniform fertiliser application regime, in order to apply $40 \mathrm{~kg}$ $\mathrm{P} / \mathrm{ha}$ to easy slopes, this rate would also have to be applied to steep slopes. Under the same system, N fertiliser could not be applied to steep slopes only. Results from Waipawa suggest that using this approach, more $\mathrm{P}$ fertiliser would be applied, but the net margin would fall to \$246/ha i.e., about \$20/ha less than from the differential approach.

The scope to obtain significant gains from differential fertiliser application obviously depends on the proportions of land in each topographic category. This relates as much to differentiation between flat and easy slopes as much as for steep slopes. In the above examples the mapped proportion of hill land in slopes greater than $25^{\circ}$ was surprisingly low i.e., 6 and $16 \%$ for the moist Manawatu and East Coast dry hill country farms respectively. This was from typically 'steep' hill country. Conversely the proportion of flat land was relatively high and it is likely that the opportunity to fertilise flat areas at different rates from easy or steep slopes, may provide the greatest gains in fertiliser use efficiency, as shown in Table 2.

The wider role for $\mathrm{N}$ fertiliser in New Zealand hill country where it can be differentially applied must also be considered. The usual strategy of $\mathrm{N}$ application is to preferentially fertilise the better growing pastures on a hill farm where responses of $10 \mathrm{~kg} \mathrm{DM} / \mathrm{kg} \mathrm{N}$ fertiliser applied or better can be obtained and fully utilised. Results from the Waipawa trial (Gillingham et al. 1998) show that much greater responses can be obtained from strata with low legume content where only low levels of associated P fertiliser are required. Differential application will allow these areas to be strategically fertilised, and, as long as the management is able to fully utilise the additional pasture, then it is likely that significant increases in productivity from a wide range of current hill country farms could be achieved.

There are a number of aspects related to the development of differential topdressing technology that have not been addressed in this paper. One is the extra cost of application of fertiliser by an aircraft equipped with the GPS technology. This will relate both to the cost of the equipment and of linking it with farm GIS information, and the cost of any extra flying time that may be involved in utilising the new technology. For example, a Cresco fixed-wing aircraft can apply about 25 tonnes per hour at a cost of $\$ 880$. If the new technology imposed an additional 50\% application cost then, according to the above analysis, and if the aircraft was applying fertiliser at $200 \mathrm{~kg} / \mathrm{ha}$, the additional cost would be $\$ 3.52 / \mathrm{ha}$. This would be still profitable. Where an alternative fertiliser such as urea was to be differentially applied, some repeat flying would be required. This can be done utilising the previous GPS flight path prescription. The second aspect is the definition of the minimum size or dimensions of management units that can be differentially fertilised within a hill block. In this paper we have used $20 \mathrm{~m}$ wide topographic units to define the general slope. In very mixed topography this would generate land units which are too small to differentially fertilise, and so the level of differentiation may be less in practice than used in these examples. The third aspect is the precision with which differing fertiliser physical forms can be placed with acceptably narrow boundary effects. This will be affected by the physical form of the fertiliser, with well-granulated fertilisers having the most narrow boundary widths. Similarly, we have made no allowance for the land areas that can be omitted completely from fertiliser application under a differential policy. Such areas are stream channels, bush areas, tracks and roadways, and maybe some steep pasture areas. This 
will generate fertiliser savings, which could be used to apply heavier rates to other, flatter sites.

\section{Conclusions}

This modelling exercise shows that differential application of fertiliser rates and types to contrasting parts of hill country according to differing specific needs and stock carrying capacities, provides optimum efficiency of fertiliser use. Greater pasture and animal production can be achieved than from the same amount of fertiliser applied uniformly over a block of typical hill land.

The relative improvement in fertiliser efficiency and farm economics appears to be greater where heavier rates of $\mathrm{P}$ fertiliser are used (i.e., Table $2 \mathrm{cf}$ Table 1), and where capital $\mathrm{P}$ fertiliser application is considered, or where some substitution of $\mathrm{N}$ (with greater relative responsiveness) for $\mathrm{P}$ fertiliser is possible (Table 3 ).

These conclusions suggest that development of the technology to provide differential fertiliser application to hill country pastures should produce worthwhile gains for the farmer. Because of the improved fertiliser efficiency achieved it should also be economically beneficial for higher fertiliser rates to be strategically used on the naturally better producing land components.

\section{ACKNOWLEDGEMENTS}

Thanks are due to M. Gray and A. Holman for the collection and processing of the pasture and animal production data from the Waipawa trial site used in the preparation of this paper. P. Espie is also thanked for the topographic definition of the Waipawa site.

\section{REFERENCES}

Chaio Yen-Shong; Gillingham, A.G. 1989. The value of stabilising fertiliser under carry-over conditions. American journal of agricultural economics 71: 352-362.

Gillingham, A.G. 1974. Influence of physical factors on pasture growth on hill country. Proceedings of the New Zealand Grassland Association 35: 77-85.

Gillingham, A.G.; Maber, J.F.; MacFarlane, M.J.; Korte, C.J.; Manning, M.J. 1985. Effects of wind and fertiliser characteristics on aerial distribution from an unmodified fixed-wing aircraft. Proceedings of the Technical Conference of the Fertiliser Manufacturer's Research Association 20: 223-239.

Gillingham, A.G.; Gray, M.H.; Smith, D.R. 1998. Pasture responses to phosphorus and nitrogen fertilisers on dry hill country. Proceedings of the New Zealand Grassland Association 60: 135-140.

Lambert, M.G.; Clark, D.A.; Grant, D.A.; Costall, D.A. 1983a. Influence of fertiliser and grazing management on North Island moist hill country. I Herbage accumulation. New Zealand journal of agricultural research 26: 95-108.

Lambert, M.G.; Clark, D.A.; Grant, D.A.; Costall, D.A. 1983b. Influence of fertiliser and grazing management on North Island moist hill country. II. Pasture botanical composition. New Zealand journal of agricultural research 29: 1-10.

Scobie, G.M.; St-Pierre, N.R. 1987. The economics of phosphorus fertiliser use on pastures, II. Incorporating the residual effect. New Zealand journal of experimental agriculture 15: 445-451. 